\title{
PENGEMBANGAN MEDIA PEMBELAJARAN PTERIDOPHYTA BERBASIS HERBARIUM
}

\author{
Salwa Rezeqi ${ }^{*}$ dan Dina Handayani \\ Program Studi Pendidikan Biologi, FMIPA Universitas Negeri Medan, \\ Jl. Williem Iskandar Psr. V Medan Estate, Medan, Indonesia, 20221 \\ *Email: salwarez@gmail.com
}

\begin{abstract}
ABSTRAK
Penelitian ini bertujuan untuk mengetahui kelayakan media herbarium yang digunakan dalam proses pembelajaran pada materi Pterydophyta. Penelitian ini merupakan penelitian pengambangan yang mengacu Dick dan Carey. Sampel yang digunakan sebanyak 50 mahasiswa yang diambil secara random sampling. Data yang diperoleh dianalisis secara deskriptif kuantitatif. Media herbarium divalidasi oleh ahli media dengan persentase 89.07\% dengan kriteria sangat layak dan validasi oleh ahli materi dengan nilai $86.46 \%$ dengan kriteria media yang dihasilkan juga sangat layak. Setelah dilakukan perbaikan sesuai dengan saran validator lalu dilanjutkan uji coba produk terhadap mahasiswa dengan nilai persentase $85.27 \%$ yang menunjukkan bahwa produk media herbarium yang dihasilkan sudah sangat baik.
\end{abstract}

Kata Kunci: media pembelajaran, herbarium, Pterydophyta

\section{ABSTRACT}

This study aims to determine the feasibility of herbarium media used in the learning process on Pterydophyta material. This research is a mining study that refers to Dick and Carey. The sample used is 50 students taken by random sampling. The data obtained were analyzed descriptively quantitatively. Herbarium media is validated by media experts with $89.07 \%$ percentage with very reasonable criteria and validation by material experts with $\mathbf{8 6 . 4 6 \%}$ value with media criteria produced also very feasible. After the improvement in accordance with the validator's suggestion and then continued product trial to students with a percentage value of $85.27 \%$ indicating that the herbarium media product produced is very good.

Keywords: learning media, herbarium, Pterydophyta

\section{PENDAHULUAN}

Taksonomi Organisme Tingkat Rendah merupakan mata kuliah wajib yang harus ditempuh mahasiswa jurusan Biologi Univesitas Negeri Medan. Tujuan umum mata kuliah ini adalah mahasiswa mampu mengidentifikasi tumbuh-tumbuhan tingkat rendah. Mata kuliah ini membahas tentang prinsip/konsep sistematika tumbuhan rendah, ciriciri pembeda pada penggolongan tumbuhan rendah dan mengenal anggota-anggota dari masing-masing golongan tersebut. Mata kuliah ini memiliki 3 SKS yang terdiri dari kegiatan teori sebesar 2 SKS dan kegiatan praktikum sebesar 1 SKS.

Dalam membelajarkan mata kuliah ini sangat diperlukan kegiatan praktikum karena kegiatan praktikum pada mata kuliah ini memberikan bekal keterampilan dan pendalaman pemahaman tentang keanekaragaman tumbuhan dengan cara melakukan praktikum di laboratorium dan habitat aslinya.

Penulis merupakan salah satu dosen pengampu pada mata kuliah Taksonomi Organisme Tingkat Rendah. Berdasarkan pengalaman penulis di lapangan yakni laboratorium Biologi Universitas Negeri Medan pada saat pelaksanaan praktikum Taksonomi Organisme Tingkat Rendah yang mana masing-masing mahasiswa dalam kelompoknya diwajibkan membawa bahan berupa tumbuhtumbuhan khususnya Ptreidophyta yang sesuai dengan materi yang akan dipelajari. Permasalahan yang didapatkan penulis ketika di lapangan yaitu bahan-bahan berupa tanaman yang dibawa setelah 
dipraktikumkan dibuang begitu saja di tempat sampah sehingga terkadang petugas kebersihan mengalami kesulitan karena jadwal praktikum bukan hanya 1 atau 2 kelas saja pada hari yang bersamaan sehingga tempat sampah di laboratorium tersebut dipenuhi oleh bahan praktikum dari mahasiswa.

Setiap kelompok diminta membawa sampel tumbuhan yang sama pada setiap praktikum, bahkan pada tahun-tahun sebelumnya maka hal ini dapat menyebabkan kelestarian tumbuhan tersebut terganggu dan lama-kelamaan akan habis. Bahan yang akan dipraktikumkan bukan hanya sekedar daunnya saja akan tetapi akar, batang dan daun yang sudah memiliki spora, jadi dapat dikatakan setiap kali praktikum berarti seorang mahasiswa akan menyebabkan kematian satu spesies Pteridophyta sehingga akan mengurangi kelestariannya karena spesies yang digunakan merupakan yang fertile.

Selain itu permasalahan yang sering dihadapi yakni tidak semua spesies tanaman dapat dihadirkan langsung pada saat perkuliahan dan komponen morfologi pada masing-masing organ tumbuhan tidak dapat dilihat sepintas lalu saja. Sesuai dengan penelitian Febriani (2013) untuk dapat memahami objek yang diamati dalam praktikum maka diperlukan tiruan objek untuk memperoleh pemahaman yang lebih jelas (febriani, 2013).

Oleh karena itu untuk mengatasi permasalahan di atas adalah perlu disusunnya media pembelajaran berupa spesimen tumbuhan yang akan dipratikumkan yang sering disebut dengan istilah herbarium. Herbarium merupakan koleksi spesimen yang telah dikeringkan/diawetkan biasanya disusun berdasarkan sistem klasifikasi. Fungsi dari herbarium yaitu untuk membantu identifikasi tumbuhan lainnya yang sekiranya memiliki persamaan ciri-ciri morfologinya.

Spesimen herbarium merupakan media yang sangat penting dalam mempelajari morfologi, dan taksonomi tumbuhan tanpa herbarium tidak mungkin melakukan studi taksonomi tumbuhan (Forman and Bridson, 1991). Selain penggunaannya yang praktis dan ekonomis, herbarium dirasa menjadi solusi dalam pembelajaran karena dapat dibawa kemana saja, baik di kelas maupun di laboratorium. Penggunaan media pembelajaran herbarium menjadi sangat diperlukan dalam proses pembelajaran biologi karena media ini dapat digunakan dalam jangka waktu yang cukup lama dan dosen dapat mengoleksi tumbuhan-tumbuhan yang jarang ditemukan disekitar lingkungan sehingga mahasiswa lebih paham dan memahami pembelajaran (Majid, 2013).

Spesimen herbarium yang baik ditentukan oleh cara mengkoleksinya dan dan proses pembuatan spesimen herbarium (Lawrence, 1986). Herbarium pada masing-masing tumbuhan Pteridophyta yang dibuat terdiri dari akar, batang, daun, sorus. Mengingat banyaknya ciri-ciri morfologi daun yang harus dipahami oleh mahasiswa dan disertai dengan bahasa latin, maka dengan herbarium ini mahasiswa lebih mudah memahami dan akan memberikan pengalaman konkret sehingga pembelajaran lebih bermakna.

Selain menggunakan media specimen segar yang menyebabkan berkurangnya kelestarian tanaman Pteridophyta, dalam proses pembelajaran para pendidik juga sering dijumpai menggunakan media power point yang berisi foto-foto literature untuk membelajarkan materi tersebut. Namun media tersbut memiliki kelemahan karena foto-foto yang ditampilkan (media gambar) menurut Arif (2006) hanya menekankan persepsi indera penglihatan saja. Padahal untuk mempelajari morfologi Pteridophyta dibutukan juga indera peraba untuk mengatahui struktur kasar atau halusnya batang dan daun tanaman paku tersebut. Maka penulis mengembangkan media pembelajaran Pterydophyta dengan membuat herbarium yang terdiri dari akar, batang dan daun yang fertile secara utuh. Media yang dikembangkan penulis menurut Raharjo yang dikutip Mahnun (2012) merupakan jenis media by design karena media tersebut dirancang, dipersiapkan dan dikembangkan sendiri sesuai dengan sarana dan kelengkapan yang ada. Media ini nantinya diharapkan dapat memberikan pemahaman yang lebih baik lagi dalam proses pembbelajaran.

\section{METODE}


Penelitian dilaksanakan di Universitas Negeri Medan pada bulan November-Desember 2017. Penelitian ini menggunakan acuan pengembangan Dick dan Carey (Trianto, 2009). Setelah herbarium dihasilkan maka dilakukan validasi oleh tim ahli materi dan ahli media. Kemudian setelah dinyatakan valid sesuai dengan saran perbaikan validator maka produk di uji coba terhadap mahasiswa Biologi semester tiga Universitas Negeri Medan yang dijadikan sebagai sampel dengan teknik random sampling. Uji coba yang dilakukan beruapa uji coba perorangan sebanyak 7 orang mahasiswa, uji coba kelompok kecil sebanyak 28 orang mahasiswa yang diambil dari perwakilan pada masing-masing kelas, dan uji coba lapangan sebanyak 50 orang mahasiswa.

Pada tahap ini mahasiswa diminta mengisi angket dengan skala likert dengan tingkatan nilai (1) tidak baik, (2) kurang baik, (3) baik dan (4) sangat baik.. Kemudian data dianalisis secara deskriptif kuantitatf, yaitu menghitung persentase indikator untuk setiap kategori pada media pembelajaran yang telah dikembangkangkan. Penghitungan data kuantitatif berupa angka penilaian dari validator ahli media, validator ahli materi dan uji coba produk terhadap mahasiswa. Nilai validasi $=$

$$
\frac{\text { Es shor hriterium }}{\text { E skor maksimal }} \times 100 \%
$$

Klasifikasi skor tersebut selanjutnya diubah menjadi klasifikasi dalam bentuk persentase, kemudian ditafsirkan dengan kalimat bersifat kuantitatif yang dikemukakan Arikunto (2002) tercatum dalam Tabel 1.

Tabel 1. Kriteria penilaian media pembelajaran yang dikembangkan

\begin{tabular}{cc}
\hline Presentasi & Kriteria \\
\hline $76-100$ & Sangat layak/baik \\
$56-75$ & Layak/baik \\
$40-55$ & Kurang layak/baik \\
$50-39$ & Tidak layak/baik \\
\hline
\end{tabular}

\section{HASIL PENELITIAN}

Pada media pemebelajaran Pterydophyta berbasis herbarium dilakukan validasi. Validasi yang dilakukan berupa validasi ahli materi dan validasi ahli media. Setelah mendapatkan saran dan perbaikan pada media tersebut lalu dilanjutkan uji coba produk terhadap mahasiswa Pendidikan Biologi FMIPA Universitas Negeri Medan. Validasi tim ahli materi dilakukan oleh Ibu Mugi Mumpuni, S.Si, M.Si dan validasi ahli media dilakukan oleh Ibu Dr. Widya Arwita, M.Pd. Adapun hasil validasi terhadap materi dapat dilihat pada tabel 2.

Tabel. 2 Skor penilaian media pembelajaran Pterydophyta oleh validator ahli materi

\begin{tabular}{ccc}
\hline Indikator Penilaian & Skor & Kriteria \\
\hline Kualitas materi pembelajaran & $91.67 \%$ & Sangat layak \\
Efek bagi strategi pembelajaran & $81.25 \%$ & Sangat layak \\
\hline Rata-rata & $\mathbf{8 6 . 4 6 \%}$ & Sangat layak \\
\hline
\end{tabular}

\section{Berdasarkan Tabel 2 dapat dilihat dari kualitas materi pembelajaran media yang}

dikembangkan sudah sangat layak dengan nilai 91.67\%. Berdasarkan hasil validasi ahli materi, media 
yang dikembangkan sudah refresentatif dan relevan dengan materi yang akan dicapai pada pembelajaran. Berdasarkan saran yang diberikan oleh validator, pada media dilakukan perbaikan terkait dengan penulisan deskripsi. Untuk membantu mahasiswa memahami deskripsi dari masing-masing spesies pada media yang kembangkan, maka bahasa yang digunakan lebih interaktif dengan tujuan agar mahasiswa sebagai pengguna tidak merasa bosan atau monoton akan informasi yang disampaikan. Sehingga pada deskripsi dicantumkan juga arti dari bahasa latin yang digunakan serta manfaat pada masing-masing spesies yang berkaitan dengan kehidupan sehari-hari.
Efek media pemelajaran yang dikembangkan sudah memberikan efek yang sangat layakbagi strategi pembelajaran dengan nilai 81.25\%. Untuk meningkatkan motivasi dalam mempelajari Pteridophyta maka tampilan pada media juga dibuat lebih menarik lagi dengan menambahkan gambar literature sesuai dengan spesies yang ada. Hal ini bertujuan untuk menambah pengetahuan akan morfologi Ptreridophyta pada saat kondisi segar walaupun hanya sebatas gambar saja. Karena pada saat pengherbariuman terdapat pada beberapa spesies mengamali perubahan warna menjadi lebih gelap. Selain validasi oleh ahli materi, juga dilakukan validasi oleh ahli media yang penilaiannya dapat dilihat pada Tabel 3.

Tabel. 3 Skor penilaian media pembelajaran pada materi Pterydophyta oleh validator ahli media

\begin{tabular}{ccc}
\hline Indikator Penilaian & Skor & Kriteria \\
\hline Bentuk media & $91.67 \%$ & Sangat layak \\
Penggunaan media & $91.67 \%$ & Sangat layak \\
Kualitas desain media & $81.25 \%$ & Sangat layak \\
Tata letak dan bahasa dalam media & $91.67 \%$ & Sangat layak \\
\hline Rata-rata & $\mathbf{8 9 . 0 7 \%}$ & Sangat layak \\
\hline
\end{tabular}

Penilaian pengembangan media pembelajaran pada materi Pteridophyta ditinjau dari tiga indikator yakni bentuk media, penggunaan media, serta tata letak/ bahasa dalam media masing-masing memperoleh nilai $91.67 \%$ dengan criteria sangat layak. Untuk kualitas desain media memperoleh nilai $81.25 \%$ yang juga memperoleh kriteria sangat layak. Masukan yang diberikan oleh validator ahli media khususnya dalam pengambilan material herbarium harus memperhatikan kelengkapan organ reproduksi berupa sorus. Dari 24 spesies yang ditemukan terdapat 4 spesies yang tidak ditemukan sorusnya yakni Selliguea triloba, Blecknum orientale, Selaginella krausiana, dan Equisetum hyemele. Hal ini terjadi karena pada saat pengambilan sampel sepies tersebut masih pada tahap gametofit. Selain itu pada format penulisan deskripsi juga dilakuan perbaikan sesuai dengan standart pembuatan herbarium mengacu pada buku The Herbarium Handbook yang ditulis oleh Forman and Bridson (1991) dengan menambahkan ketinggian pengambilan spesimen dan gambar literature dari masing-masing spesies. Buku The Herbarium Handbook dijadikan oleh ahli taksonomi sebagai buku panduan prosedur pembuatan herbarium.

Kondisi herbarium yang dihasilkan masih dilakukan perbaikan dikarenakan masih ditemukan spesimen yang berjamur pada spesies Blecknum orientale, Asplenium nidus, dan Thelypteris sp yang disebabkan pada saat pengovenan waktu yang diberikan kurang lama. Sehingga dilakukan remounting (penempelan kembali) terhadap sampel yang dimulai dengan tahap penyemprotan alcohol ulang dan pengovenan kembali.

Berdasarkan penilaian kelayakan materi dan kelayakan media yang meliputi bentuk media, penggunaan media, kualitas desain media, tata ruang dan bahasa media, kualitas materi pembelajaran, dan efek media terhadap strategi 
pembelajaran, maka media herbarium Pterydophyta ini dinyatakan "layak" untuk selanjutnya digunakan dalam pembelajaran Taksonomi Organisme Tingkat Rendah dengan revisi sesuai saran. Setelah dilakukan perbaikan terhadap media herbarium sesuai dengan saran validator, maka dilanjutka uji coba produk Adapun hasil uji coba produk terhadap mahasiswa dapat dilihat pada Tabel 4.

Tabel. 4 Skor penilaian uji coba keterbacaan media pembelajaran pada materi Pterydophya

\begin{tabular}{|c|c|c|c|c|}
\hline Pernyataan & $\begin{array}{c}\text { Uji Coba } \\
\text { Perorangan }\end{array}$ & $\begin{array}{l}\text { Uji Coba } \\
\text { Kelompok }\end{array}$ & $\begin{array}{l}\text { Uji Coba } \\
\text { Lapangan }\end{array}$ & Rata-rata \\
\hline $\begin{array}{l}\text { 1. Mudah digunakan secara mandiri } \\
\text { maupun di dalam kelas }\end{array}$ & $85.71 \%$ & $82.76 \%$ & $89.50 \%$ & $85.99 \%$ \\
\hline 2. Mudah dibawa/disimpan & $78.57 \%$ & $79.31 \%$ & $76.50 \%$ & $78.13 \%$ \\
\hline 3. Efektivitas waktu penggunaan & $85.71 \%$ & $87.07 \%$ & $80.00 \%$ & $84.26 \%$ \\
\hline 4. Kelengkapan deskripsi & $85.71 \%$ & $81.90 \%$ & $80.50 \%$ & $82.70 \%$ \\
\hline 5. Kejelasan morfologi & $82.14 \%$ & $82.76 \%$ & $84.00 \%$ & $82.97 \%$ \\
\hline 6. Pemahaman istilah latin pada deskripsi & $82.76 \%$ & $82.76 \%$ & $79.50 \%$ & $81.67 \%$ \\
\hline 7. Relevan media dengan materi & $82.14 \%$ & $85.35 \%$ & $88.50 \%$ & $85.33 \%$ \\
\hline 8. Kemudahan memahami deskripsi & $96.43 \%$ & $86.21 \%$ & $91.50 \%$ & $91.38 \%$ \\
\hline 9. Ketepatan cakupan materi & $92.86 \%$ & $87.07 \%$ & $81 \%$ & $86.98 \%$ \\
\hline $\begin{array}{l}\text { 10. Kemampuan media meningkatkan } \\
\text { motivasi }\end{array}$ & $100.00 \%$ & $84.48 \%$ & $95.50 \%$ & $93.33 \%$ \\
\hline Rata-rata & $87.20 \%$ & $83.97 \%$ & $84.65 \%$ & \\
\hline Rata-rata uji coba produk & \multicolumn{4}{|c|}{$85.27 \%$ ( Sangat Baik) } \\
\hline
\end{tabular}

Berdasarkan uji coba produk yang telah dlakukan, dapat dilihat bahwa media pembelajaran herbarium pada materi Pterydophyta mendapat kriteria "sangat baik" dengan rata-rata $85.27 \%$. Penilaian uji coba produk yang paling tinggi diperoleh pada item pernyataan yang berkaitan dengan kemampuan media herbarium dalam meningkatkan motivasi yakni sebesar 95.50\%. Hal ini sejalan dengan penelitian Windayati dkk (2016) yang menyatakan bahwa media pembelajaran menggunakan herbarium membuat peserta didik termotivasi karena hal tersebut merupakan hal yang baru sehingga peserta didik lebih tertarik lagi mempelajari materi yang disajikan.

Media pembelajaran yang dapat dikatan baik adalah media yang mampu meningkatkan motivasi pembelajar dan juga dapat merangsang pembelajar mengingat apa yang sudah dipelajari selain memberikan ransangan belajar yang baru (Nandi, 2006). Selain itu media pembelajaran juga harus dapat meningkatkan dan mengarahkan perhatian peserta didik, sehingga dapat menimbulkan motivasi belajar, interaksi yang lebih langsung dengan lingkungannya dan mampu memberi kesempatan kepada peserta didik untuk dapat belajar secara mandiri sesuai denagn kemapuan dan minatnya (Kustandi dan Bambang, 2011)

Persentase yang paling rendah pada uji coba produk adalah pada pernyataan penggunaan media terkait dengan keefektifan dalam penyimpanan ataupun kemudahan membawa media tersebut yakni $78.13 \%$ namun masih tergolong kriteria sangat baik. Menurut mahasiswa ukuran media herbarium yang dihasilkan terlalu besar dengan ukuran $30 \times 40 \mathrm{~cm}$. Sehingga mahasiswa memberi tanggapan dengan ukuran yang sedemikian membuat kesulitan dalam penyimpanan khususnya apabila dimasukkan ke dalam tas untuk dapat dibawa. Namun berdasarkan prosedur handbook pengherbariuman ukuran sampel biasanya 30x40 cm dengan memperhatikan kelengkapan organ berupa akar, batang dan daun yang fertil. Apabila ukuran sampel lebih dari $30 \times 40 \mathrm{~cm}$ maka hal yang harus 
diperhatikan adalah organ pada tanaman tidak boleh dipotong ataupun dipisahkan namun cukup dilakukan pelipatan saja sesuai dengan kertas mounting (Murni dkk, 2015). Hal ini bertujuan agar tetap tidak merubah struktur tubuh seperti kondisi aslinya di alam.

\section{KESIMPULAN}

Berdasarkan penelitian maka dapat disimpulkan bahwa pengembangan media pembelajaran menggunakan herbarium pada materi Pteridophyta secara keseluruhan tergolong kategori "Sangat Layak". Berdasarkan validasi tim ahli materi terhadap media pembelajaran pada materi Pterydophyta menyatakan media yang dihasilkan "Sangat Layak" dengan persentase $86.46 \%$, dan ahli media juga termasuk kedalam kategori "Sangat Layak" dengan nilai 89.07\%. Begitu juga pada uji coba produk yang dilakukan terhadap mahasiswa setelah dilakukan perbaikan sesuai masukan para validator, maka persentase nilai yang diperoleh $85.27 \%$ yang menunjukkan bahwa produk media herbarium yang dihasilkan sudah sangat baik.

\section{DAFTAR PUSTAKA}

Arif, Sadiman. 2006. Media Pendidikan: Pengertian, PengembangandanPemanfaatannya, Jakarta: Raja Grafindo Persada.

Arikunto, S. 2002. Dasar-Dasar Evaluasi Pendidikan. Bumi Aksara. Jakarta.

Danim, Sudarwan. 1995. Media Komunikasi Pendidikan.Jakarta: Bumi Aksara.

De Vogel EF. 1987. Manual of Herbarium Taxonomi Theori and Practice. Rijksherbarium Leiden The Netherlands: Unesco.

Febriani, N. Yelianti, U. dan Gardjito. 2013. Pengembangan Pembelajaran Berupa Awetan Daun Untuk Mata Kuliah Struktur Tumbuhan Pada Prodi Pendidikan Biologi. Prosiding Semirata FMIPA Universitas Lampung.

Forman, L. and Bridson, D. 1991. The Herbarium Handbook. Rotal Botani Gardens.
Kartawianta K. 1980. Beberapa Catatan Tentang Cara-cara Pembuatan dan Pengawetan Contoh Herbarium. Bogor: Herbarium Bogoriense.

Kustandi, C. dan Bambang, S. 2011. Media Pembelajaran. Bogor: Ghalia Indonesia

Lawrence GHM. 1968. Taxonomi of Vascular Plants. New York: The Mac Millan Company.

Mahnun, N. 2012. Media Pembelajaran (Kajian terhadap Langkah-langkah Pemilihan Media dan Implementasinya dalam Pembelajaran. Jurnal Pemikiran Islam. 37(1): 27-33.
Majid, I., (2013) , Pengembangan Media Pembelajaran Herbarium Pada Siswa Madrasah Aliyah Kota Ternate, Jurnal Bioedukasi. 2(1):192-195.

Murni P, Muswita, Harlis, Yelianti U, Kartika DW. 2015. Lokakarya Pembuatan Herbarium Untuk Pengembangan Media Pembelajaran Biologo Di MAN Cendikia Muaro Jambi. JurnalPengabdian Pada Masyarakat. 30(2):1-6.

Nandi. 2006. Penggunaan Multimedia Interaktif Dalam Pembelajaran Geografi Dipersekolahan. Jurnal GEA. 6(1): 1-9

Raharjo, R. 1986. Media Pembelajaran. Jakarta: Rajawali.

Riduwan. 2012. Belajar Mudah Penelitian. Bandung: Alfabeta.

Rusdi, Susilana dan Cepi, Riyana. 2007. Media Pembelajaran Hakikat Pengembangan, Pemanfaatan, Penilaian. Bandung: Wacana Prima

Rugayah, Retnowati A, Windadri FI, Hidayat A. 2004. Pengumpulan Data Taksonomi. Di dalam: Rugayah, Widjaja EA, Praptiwi, editor. Pedoman Pengumpulan Data Keanekaragaman Flora. Bogor (ID): PuslitLIPI.

Tjitrosoepomo G. 1991. Taksonomi Tumbuhan (Scizophyta, Thallophyta, Bryophyta, Pterydophyta). Yogyakarta (ID): Gadjah Mada University Press. 
JURNAL PELITA PENDIDIKAN VOL. 6 NO. 1

pISSN : 2338 - 3003

Rezeqi, S., Handayani, D.

eISSN : 2502 - 3217

Halaman : 036 - 041

Trianto.2009. Mendesain Model Pembelajaran Inovatif-Progresif. Surabaya: Prenada Media.

Windayati P, Afifah N, Karni R. 2017. Pengembangan Media Pembelajaran Herbrium Pada Materi Organ Tumbuhan Di SMP Negeri 5 Rambah Hilir. E-Journal Mahasiswa Prodi Biologi. 3(1): 1-6.

Yusufhadi, Miarso, dkk. 1986. Teknologi Komunikasi Pendidikan. Jakarta: Rajawali. 